\title{
The collection and database of Birds of Angola hosted at IICT (Instituto de Investigação Científica Tropical), Lisboa, Portugal
}

\author{
Miguel Monteiro ${ }^{1,2}$, Luís Reino², Pedro Beja ${ }^{2}$, Michael Stuart Lyne Mills, \\ Cristiane Bastos-Silveira, 5 , Manuela Ramos', Diana Rodrigues, \\ Isabel Queirós Neves ${ }^{5,6}$, Susana Consciência', Rui Figueira' ${ }^{1,2}$
}

I Instituto de Investigação Científica Tropical, R. da Junqueira, 86 - 10, 1300-344, Lisboa, Portugal 2 CIBIO, Centro de Investigação em Biodiversidade e Recursos Genéticos / InBIO, Universidade do Porto, Vairão, Portugal 3 Percy FitzPatrick Institute of African Ornithology, DST/NRF Centre of Excellence, University of Cape Town, South Africa 4 A. P. Leventis Ornithological Research Institute, University ofJos, PO Box 13404, Jos, Plateau State, Nigeria 5 CESAM-Centre for Environmental and Marine Studies, Universidade de Aveiro, Aveiro, Portugal 6 Museu Nacional de História Natural e da Ciência, Universidade de Lisboa, Portugal

Corresponding author: Rui Figueira (rui.figueira@iict.pt)

Academic editor: V. Chavan | Received 10 October 2013 | Accepted 10 February 2014 | Published 11 March 2014

Citation: Monteiro M, Reino L, Beja P, Mills MSL, Bastos-Silveira C, Ramos M, Rodrigues D, Neves IQ, Consciência S, Figueira R (2014) The collection and database of Birds of Angola hosted at IICT (Instituto de Investigaçáo Científica Tropical), Lisboa, Portugal. ZooKeys 387: 89-99. doi: 10.3897/zookeys.387.6412

Resource Citation: Instituto de Investigação Científica Tropical (2013) IICT Bird Collection of Angola. 1560 records, Contributed by Mumputu D, Rosa Pinto A, Carlos J, Ferreira A, Nóbrega F, Pereira A, Samahina L, Loureiro M, Simóes E, Morato F, Hangula L, Pontes L, Sousa D, Gouveia M, Ramos A, Barroso J, published online, http:// maerua.iict.pt/ipt/manage/resource.do?r=iict_bird_angola, released on 01 September 2013. GBIF Key of parent collection: http://gbrds.gbif.org/browse/agent?uuid=c690c2b5-8002-4d12-831c-9258dd618f78, Data Paper doi: 10.3897/zookeys.387.6412

\begin{abstract}
The bird collection of the Instituto de Investigação Cientítica Tropical (Lisbon, Portugal) holds 5598 preserved specimens (skins), mainly from Angola, Mozambique, Guinea-Bissau, São Tomé and Principe, and Cape Verde. The subset collection from Angola includes 1560 specimens, which were taxonomically revised and georeferenced for the publication of this data paper. The collection contains a total of 522 taxa, including 161 species and 361 subspecies. Two species are classified by the IUCN Red List as Endangered
\end{abstract}

Copyright Miguel Monteiro et al. This is an open access article distributed under the terms of the Creative Commons Attribution International License (CC BY 4.0), which permits unrestricted use, distribution, and reproduction in any medium, provided the original author and source are credited. 
- the wattled crane (Grus carunculata) and the Gabela bush-shrike (Laniarius amboimensis) - and two are classified as vulnerable - African penguin (Spheniscus demersus) and the white-headed vulture (Trigonoceps occipitalis). The temporal span of the database ranges between 1943 and 1979, but 32\% are from years $1958-1959$, and $25 \%$ from years 1968-1969. The spatial coverage of the collection is uneven, with $2 / 3$ of the records representing only four of the eighteen provinces of the country, namely Huíla, Moxico, Namibe and Cuanza Sul. It adds, however, valuable information for the Huíla area of the Angolan Scarp, which is probably a biodiversity hotspot of global conservation priority. Furthermore, this georeferenced database adds invaluable bird information to the GBIF network, for one of the countries with highest but less known biodiversity in Africa.

\section{Keywords}

Occurrence, Specimen, Angola, Instituto de Investigação Científica Tropical (IICT), Animalia, Chordata, Aves

\section{Introduction}

Angola is one of the countries in Africa with highest bird diversity (938 native species, according to Mills and Melo (2013)), including a high number of endemic and threatened species (Stattersfield et al. 1998). It encompasses four main types of ecosystems: Congo lowland basin forests in the north, Angolan miombo woodlands in the centre, Zambesian miombo woodlands in the east, and Namib Desert in the south-west (Dean 2000). Despite its richness, Angola is still one of the least known countries for birds. This lack of knowledge is mainly a consequence of both the Portuguese Colonial war (1961-1974) and the Angolan civil war (1974-2002), which together lasted 41 years (1961-2002), halting scientific studies and expeditions (Dean 2000). Since the end of the civil war, Angolan society and government have focused primarily on infrastructure reconstruction and economic development, with limited attention given to scientific research and natural history studies.

Even today, basic information on Angolan bird species dates mostly from before the national independence in 1974 (Dean 2000, Ministry of Environment 2009). Some recent work has updated our knowledge to some degree (Ryan et al. 2004, Mills 2009, 2010, Mills and Dean 2007, Mills et al. 2011, 2013), including the publication of a national check-list (Mills and Melo 2013). However, historical collections still play a major role in the description of the country's biodiversity. Access to the substantial information collected on the Angolan avifauna is of great importance, considering that the IUCN Red List indicates, the occurrence in the country of one critically endangered, 14 endangered and 10 vulnerable bird species (IUCN 2013). Records should thus be made available in a form that can be readily found and used.

In this paper we provide a comprehensive dataset based on the digitalization, taxonomic revision and georeferencing of the Angolan ornithological collection held by the Instituto de Investigação Científica Tropical (IICT), Lisbon. The dataset is freely available via the Internet, on the IICT IPT provider (http://maerua.iict.pt/ipt), and on the 
Global Biodiversity Information Facility (GBIF) data portal (http://www.gbif.org). It comprises information on 1560 specimens collected in 291 localities throughout Angola. The specimens were collected in expeditions carried out between 1949 and 1979, by 64 collectors. The collection contains some very valuable skins of endemic species, such as of the endemic Red-crested Turaco (Tauraco erythrolophus (Vieillot, 1819)) and Grey-striped Francolin (Pternistis griseostriatus (Ogilvie-Grant, 1890)). It also contains skins of species listed as conservation concern in IUCN Red List, including two endangered species (the wattled crane (Grus carunculata (Gmelin, JF, 1789)) and the Gabela bush-shrike (Laniarius amboimensis Moltoni, 1932)), of which there are few skins in other collections (Dean 2000). There are also two species classified as vulnerable (African penguin (Spheniscus demersus (Linnaeus, 1758)) and the white-headed vulture (Trigonoceps occipitalis (Burchell, 1824))).

\section{General description}

The dataset is a subset of the parent bird collection of the Instituto de Investigação Cientítica Tropical, which holds 5598 preserved specimens (skins), mainly from Angola, Mozambique, Guinea-Bissau, São Tomé and Principe, and Cape Verde, available through GBIF at http://maerua.iict.pt/ipt/resource.do?r=iict_cz. The collection scrutinized through this data paper is the subset from Angola, which includes 1560 specimens that were taxonomically revised and georeferenced. The collection shares the largest collectors (A. Rosa Pinto, D. Mumputu and J. Carlos) with the related biggest collection of birds of Angola, based on Instituto Superior de Ciências de Educação da Huíla (ISCED-Huíla), in Lubango. That institute inherited the collections of the former Instituto de Investigação Científica de Angola (IICA), including a bird collection with more than 35 thousand specimens, making it the largest in Africa. Although showing an uneven geographic distributions of samples, with $2 / 3$ of the records concentrated in only four provinces (Huíla, Moxico, Namibe and Cuanza Sul), the collection adds, invaluable information for the Huila's area of the Angolan Scarp, which is probably a biodiversity hotspot of global conservation priority (Myers et al. 2000), and an important area of bird endemism (Mills 2010).

\section{Project details}

Project title: Online Catalogue of Biological Collections of IICT

Funding: This project was funded by the Fundação para a Ciência e a Tecnologia (FCT) through the project "Recovering the past, recording the present, and preparing the future of zoological collections in Portugal (ARCA)" (PTDC/BIAQOR/71492/2006) and co-funded by CIBIO, Centro de Investigação em Biodiversidade e Recursos Genéticos / InBIO from the University of Porto. 


\section{Taxonomic coverage}

General taxonomic coverage description: The taxonomic coverage of this dataset spans class, and it includes 24 orders and 69 families (Figure 1). Nearly two thirds of the specimens belong to the order Passeriformes. The Coraciiformes order ranks second, with $5 \%$ of the specimens. The families Cisticolidae, Estrildidae and Ploceidae have the highest number of records (136, 114 and 113 records respectively) (Figure 2). The families with fewest records are Bucorvidae, Ciconiidae, Picidae, Spheniscidae, Trogonidae, Turnicidae and Tytonidae, with one record each. The database contains 522 taxa (161 species and 361 subspecies).

\section{Taxonomic ranks}

Kingdom: Animalia

Phylum: Chordata

Class: Aves

Order: Accipitriformes, Anseriformes, Apodiformes, Bucerotiformes, Caprimulgiformes, Charadriiformes, Ciconiiformes, Coliiformes, Columbiformes, Coraciiformes, Cuculiformes, Falconiformes, Galliformes, Gruiformes, Musophagiformes, Passeriformes, Pelecaniformes, Piciformes, Podicipediformes, Psittaciformes, Pterocliformes, Sphenisciformes, Strigiformes, Trogoniformes

Family: Accipitridae, Alaudidae, Alcedinidae, Anatidae, Apodidae, Ardeidae, Bucerotidae, Bucorvidae, Campephagidae, Caprimulgidae, Certhiidae, Charadriidae, Ciconiidae, Cisticolidae, Coliidae, Columbidae, Coraciidae, Cuculidae, Dicruridae, Emberizidae, Estrildidae, Eurylaimidae, Falconidae, Fringillidae, Glareolidae, Gruidae, Hirundinidae, Indicatoridae, Jacanidae, Laniidae, Laridae, Malaconotidae, Meropidae, Monarchidae, Motacillidae, Muscicapidae, Musophagidae, Nectariniidae, Numididae, Oriolidae, Otididae, Paridae, Passeridae, Phalacroracidae, Phasianidae, Phoeniculidae, Picidae, Platysteiridae, Ploceidae, Podicipedidae, Psittacidae, Pteroclidae, Pycnonotidae, Rallidae, Ramphastidae, Remizidae, Scolopacidae, Spheniscidae, Strigidae, Sturnidae, Sylviidae, Timaliidae, Trogonidae, Turdidae, Turnicidae, Tytonidae, Upupidae, Viduidae, Zosteropidae

Common names: Birds

\section{Spatial coverage}

General spatial coverage: The geographic range of the collection covers the whole Angola. Distribution of sampling locations is presented in Figure 3, including counts of records per grid cell, in a half a minute grid. The distribution among the Angolan provinces is uneven, with the following series: Huíla (320), Moxico (293), Namibe (202), Cuanza Sul (166), Cuanza Norte (107), Cunene (88), Cuando Cubango (54), 


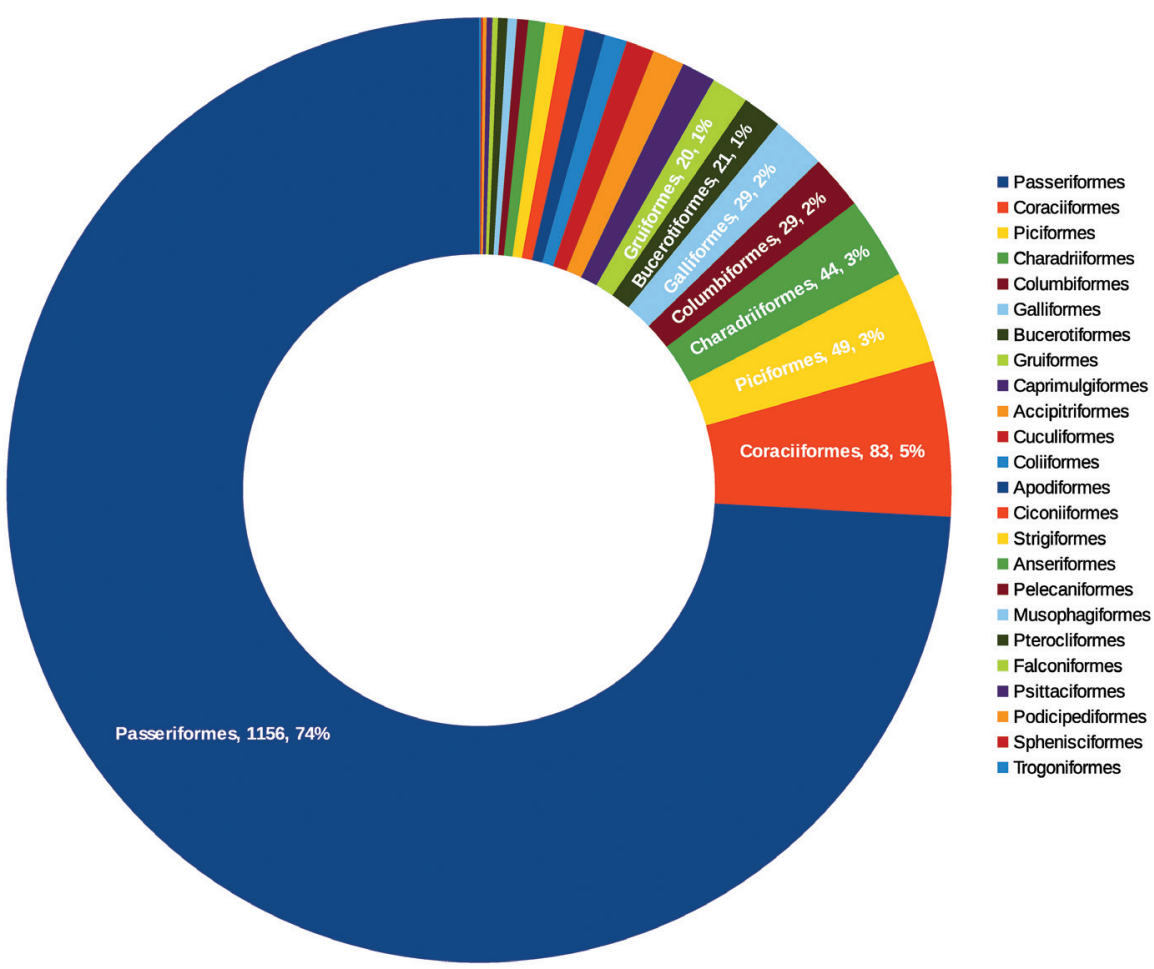

Figure I. Number and percentage of specimens per orders. Only the categories of orders having 20 or more specimens are labeled.

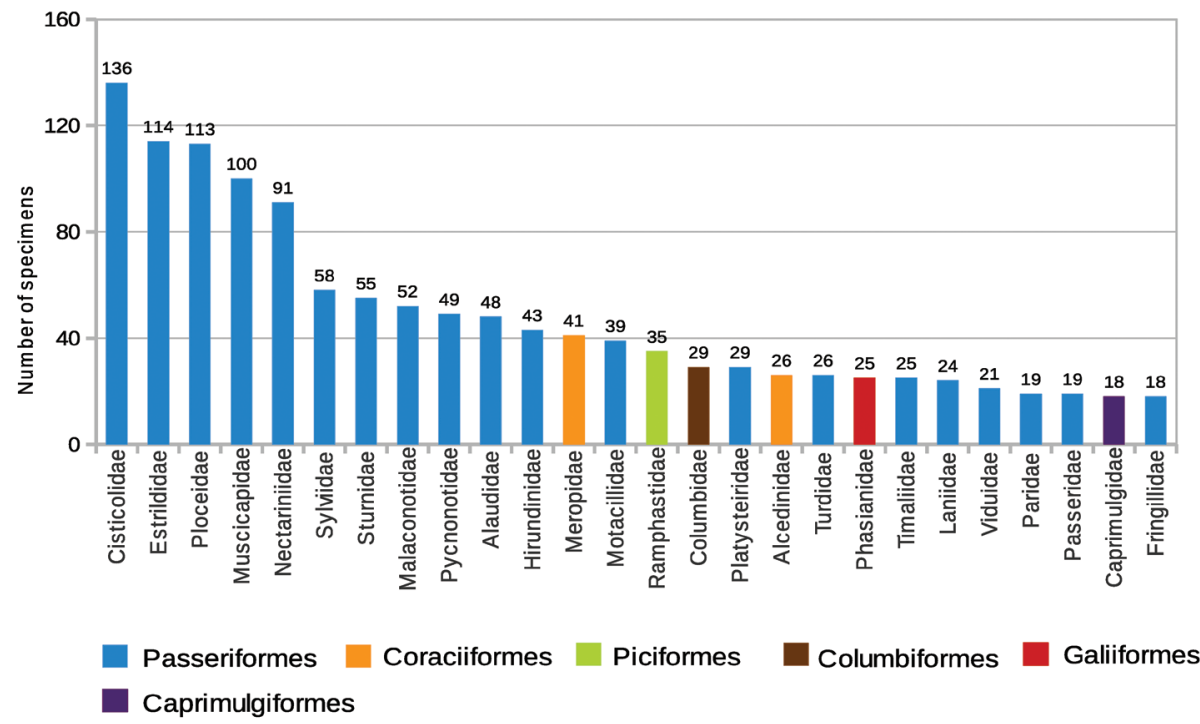

Figure 2. Number of specimens per family. The families pictured represent $80 \%$ of the number of specimens in the collection. 


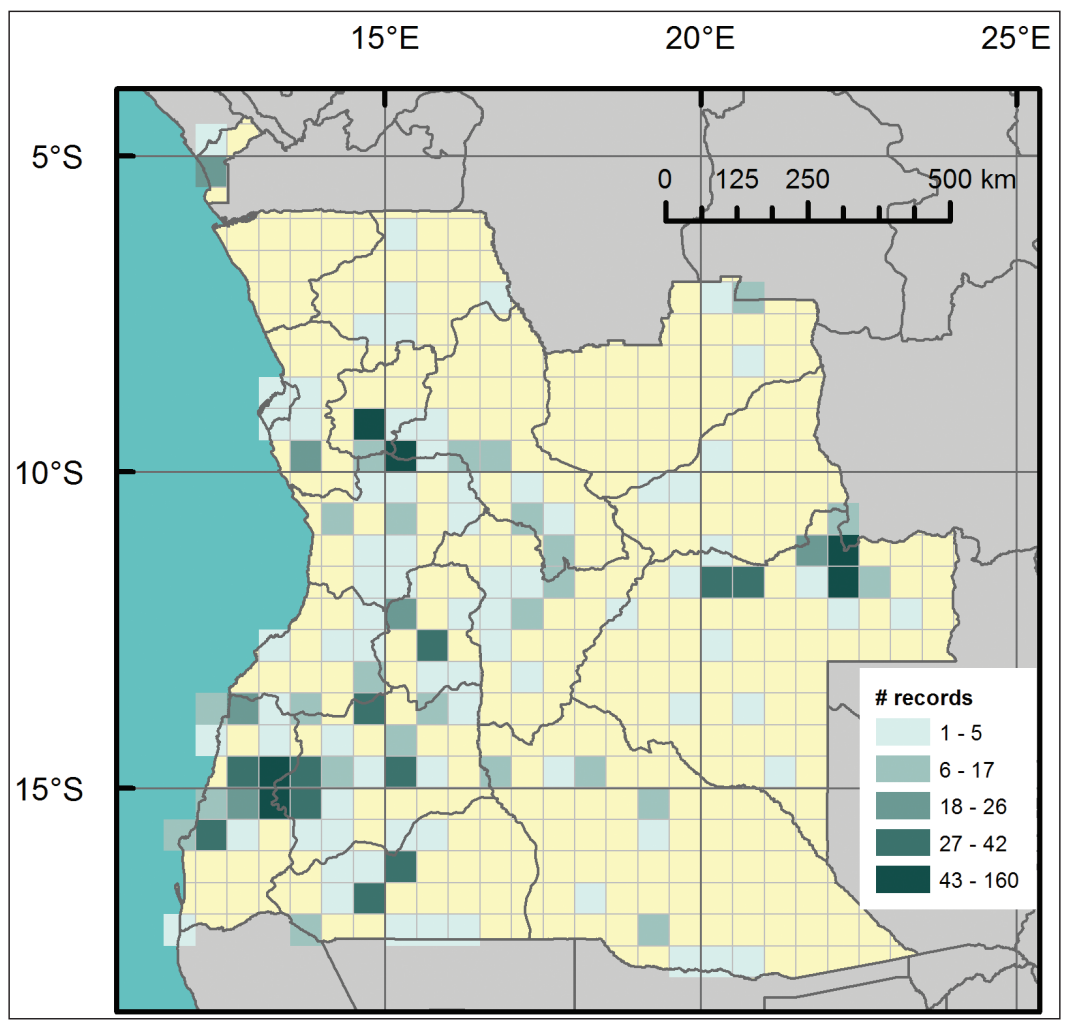

Figure 3. Distribution of occurrence records with indication of number of records indicated on a half a minute grid system.

Huambo (51), Malanje (51), Benguela (35), Bengo (29), Cabinda (26), Bie (21), Lunda Norte (16), Lunda Sul (9), Uige (9), Luanda (1). No records occur in the province of Zaire, in the north-west region of Angola. The province of collection is unknown for 82 specimens. The research unit in Angola where the main collectors where based was located in Huíla, which justifies the highest value found for that province.

\section{Coordinates}

$18^{\circ} 30^{\prime} 36^{\prime \prime S}$ and $4^{\circ} 5^{\prime} 60^{\prime \prime S}$ Latitude; $10^{\circ} 2^{\prime} 24^{\prime \prime E}$ and $24^{\circ} 51^{\prime} 0$ "E Longitude

\section{Temporal coverage}

The temporal range of the records is between 1943 and 1979, (Figure 4). Two peak periods are observed, in 1958-1959, and in 1968-1968, with more than 200 samples per year. 


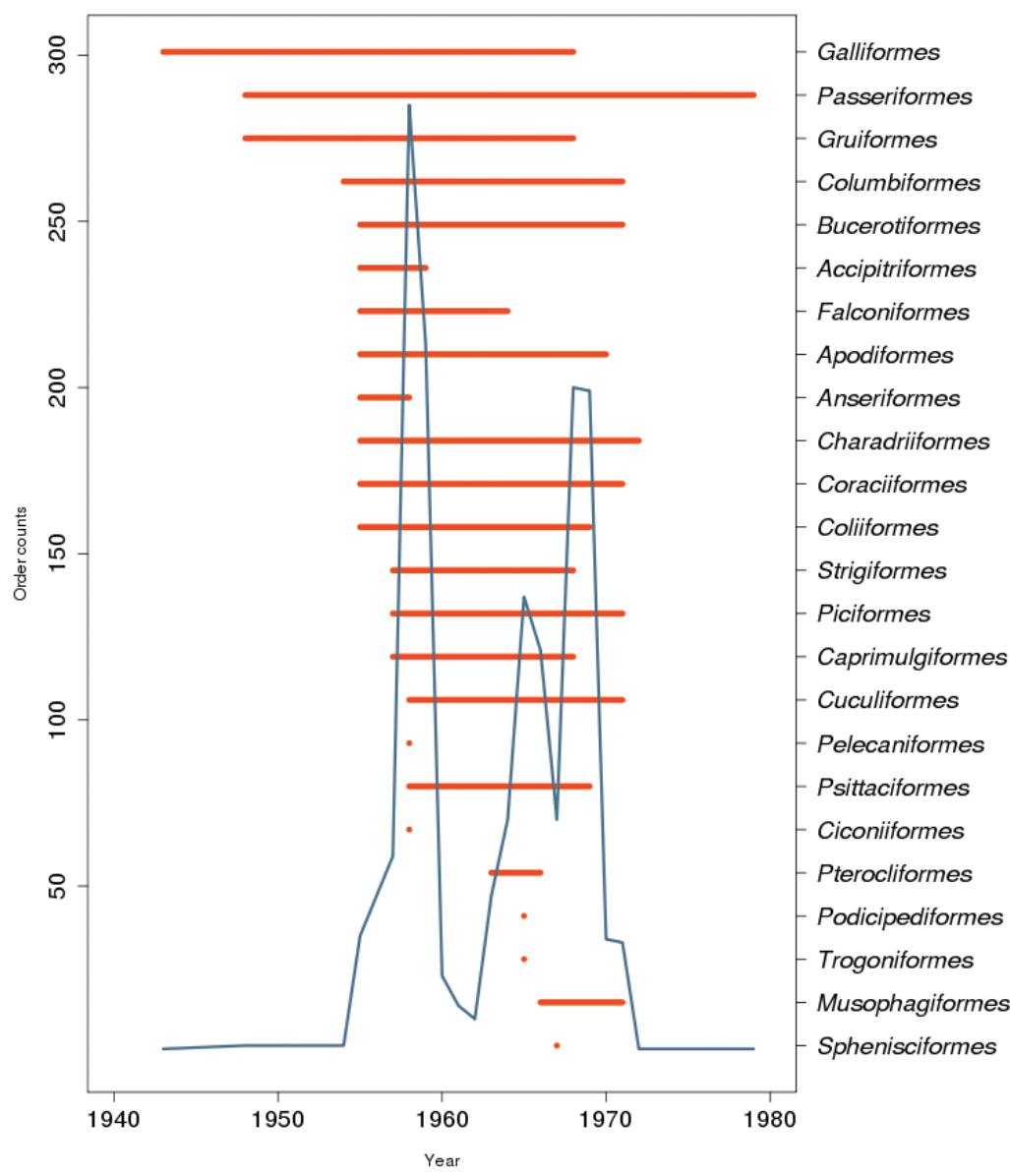

Figure 4. Temporal profile of the specimens in the collection. The time range for each order is represented by the horizontal bars.

\section{Natural collections description}

Parent collection identifier: 24798813 -aaff-4292-98ef-8c9bc415ff14

Collection name: IICT - Colecção de Aves de Angola

Collection identifier: 9B48F857-91B6-4029-9AEF-A80F7852EC89

Specimen preservation method: Dried

Curatorial unit: 1560 with an uncertainty of 0 (skins)

\section{Methods}

Method step description: The general procedure for the processing of specimens databasing and georeferencing is represented in Figure 5. The mammal and bird collections of the IICT were initially catalogued under the scope of project ARCA (2008-2010), 


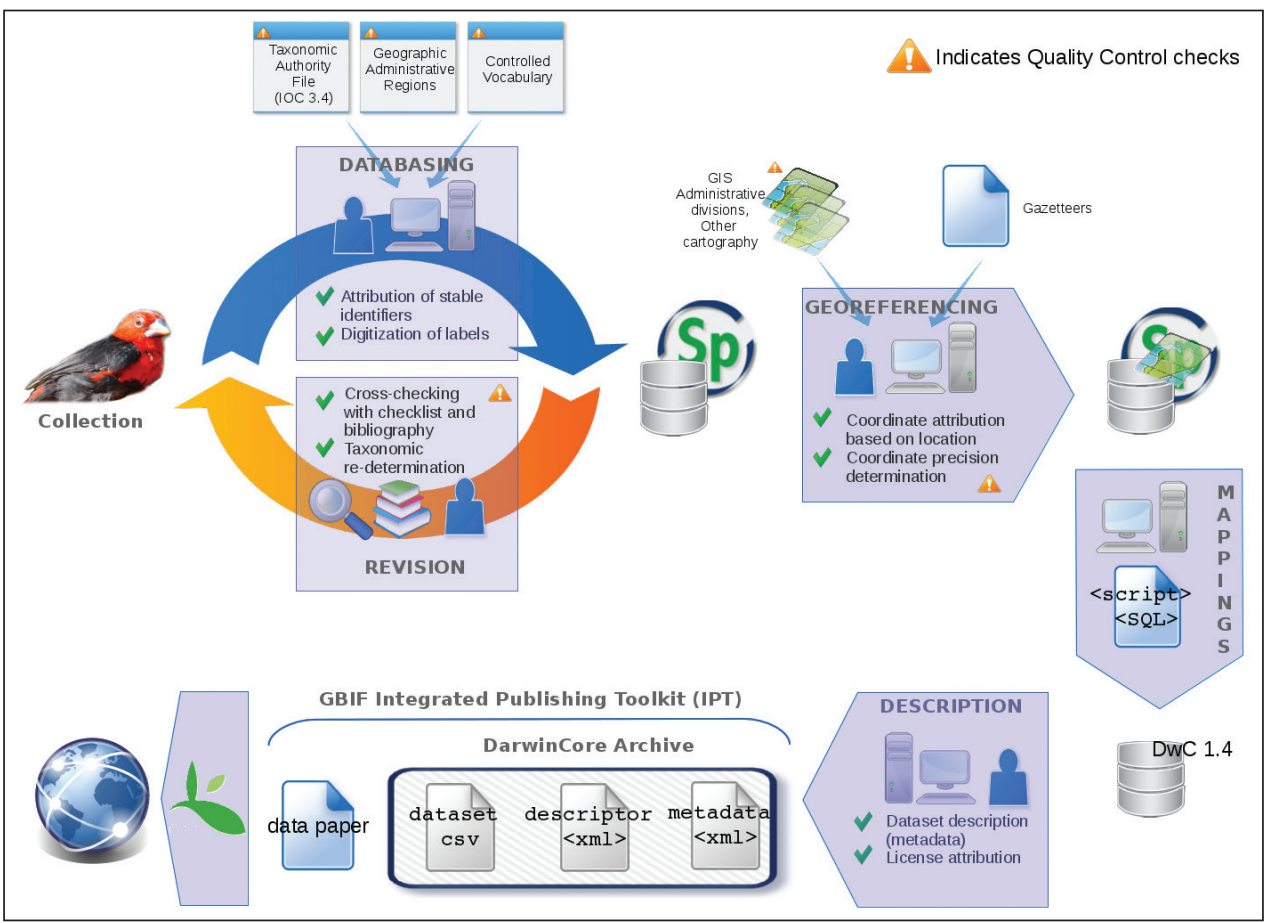

Figure 5. Synoptic of the procedure to digitize and publish the dataset online.

using the software Specify Workbench, and afterwards imported to software Specify version 6 (Specify Software Project 2013). Whenever available, the descriptions of eye, beak and foot colour, and total length were also included.

Since at that time no taxonomic specialists were available to revise the collection, records were catalogued as they were labelled, without taxonomic revision or update of taxonomic names.

In 2012-2013, the IICT collection of Angolan birds was fully taxonomically revised. This taxonomic revision followed the IOC bird list (Gill and Donsker 2013) and all skins were labelled with a new catalogue number and the original information was thereafter included in the collection manager software Specify 6. Additionally, the specimens' original information was re-checked at this phase for any initial cataloguing errors.

Since no georeferencing information was available on specimen labels or associated documentation, geographic coordinates were determined following procedure and recommendations by Chapman and Wieczorek (2006). Several geographic gazetteers were used to determine coordinates, based on the location information: Geolocate, Google Maps, Google Earth. Furthermore, the cartographic series 1:100 000 of Angola was used to find additional sites not available at gazetteers or to fine-tune coordinate uncertainty. The uncertainty of the coordinate was recorded whenever possible. For 88 records it was not possible to determine coordinates due to insufficient location information. All coordinates are given in geographic format, decimal degrees, datum WGS 84. 
Study extent description: The study covers most of Angola, including 17 out of the 18 provinces. The best-represented provinces are Huíla, Moxico, Namibe and Cuanza Norte. Only the province of Zaire (NW Angola) is not represented in the collection. The temporal distribution is mainly concentrated in the decades of 1950 s (especially in years 1958 and 1959) and 1960s, corresponding to $95 \%$ of the records.

Sampling description: More than one thousand records of this dataset resulted from expeditions and studies carried out by the former Section of Ornithology at the Instituto de Investigaçáo Científica de Angola, coordinated by António Augusto da Rosa Pinto between 1958 and 1974. Some scientific results of these studies, for the non-passerine group were published in Rosa Pinto (1983).

Quality control description: Information from each specimen was catalogued in Specify 6, which involved two steps: i) digitalization of specimen's records (performed by MR, DR, IQN and SC); and ii) taxonomic revision and data checking (performed by the first author). The authors LR and MM also contributed to taxonomic revision of the specimens. Scientific names were checked with a taxonomic thesaurus built from the IOC World Bird List (v 3.34) (Gill and Donkster 2012). Georeferencing followed recommendations by Chapman and Wieczorek (2006), including the determination of uncertainty of coordinates, in particular when no sufficient information was available from the specimens' records and label, to attribute a specific locality of origin (e.g. names of administrative regions, names of rivers).

\section{Datasets}

\section{Dataset description}

Object name: Darwin Core Archive The collection and database of Birds of Angola hosted at IICT (Instituto de Investigação Científica Tropical), Lisboa, Portugal

Character encoding: UTF-8

Format name: Darwin Core Archive format

Format version: 1.0

http://maerua.iict.pt/ipt/archive.do?r=iict_bird_angola

Distribution: http://maerua.iict.pt/ipt/archive.do?r=iict_bird_angola

Publication date of data: 2013-10-09

Language: Portuguese

Licenses of use: Use of the data for commercial or for-profit applications is permitted only via written permission from Instituto de Investigação Científica Tropical. Data are provided to users, but should not be passed on to third parties or redistributed. It is explicitly forbidden to incorporate these data into other databases of free or restricted access.

Metadata language: English

Date of metadata creation: 2013-08-22

Hierarchy level: Dataset 


\section{Acknowledgements}

We are grateful to Prof. Maria Teresa Ferreira from the Instituto Superior de Agronomia (Universidade de Lisboa) for helping us in supporting the Master studies of Miguel Monteiro, and to Joana Figueiredo Santana (CIBIO/InBIO) for the all the assistance. Luís Reino was supported by FCT - Fundação para a Ciência e a Tecnologia, through the Post-doctoral grant SFRH/BPD/62865/2009, and Rui Figueira through Compromisso com a Ciência 2007 Programme.

\section{References}

\section{1) References cited within the metadata}

Dean WRJ (2000) The Birds of Angola. BOU Checklist Series 18. British Ornithologist's Union, Tring, UK.

IUCN (2013) IUCN Red List of Threatened Species. Version 2013.1. www.iucnredlist.org [accessed on 05 November 2013]

Mills MSL (2010) Angola's central scarp forests: patterns of bird diversity and conservation threats. Biodiversity and Conservation 19: 1883-1903 doi: 10.1007/s10531-010-9810-4

Mills MSL (2009) Vocalisations of Angolan birds: new descriptions and other notes. Bull. ABC 16: 150-166.

Mills MSL, Dean W (2007) Notes on Angolan birds: new country records, range extensions and taxonomic questions. Ostrich 78: 55-63 doi: 10.2989/OSTRICH.2007.78.1.9.53

Mills MSL, Melo M (2013) The Checklist of the Birds of Angola. Associação Angolana para Aves e Natureza and Birds Angola, Luanda, 75 pp.

Mills MSL, Melo M, Vaz A (2013) The Namba mountains: new hope for Afromontane forest birds in Angola. Bird Conservation International 23: 159-167. doi: 10.1017/ S095927091200024X

Mills MSL, Olmos F, Melo M, Dean WRJ (2011) Mount Moco: its importance to the conservation of Swierstra's Francolin Pternistis swierstrai and the Afromontane avifauna of Angola. Bird Conservation International 21: 119-133 doi: 10.1017/S0959270910000493

Ministry of Environment (2009) Framework report of Angola's Biodiversity. Republic of Angola, Luanda, $60 \mathrm{pp}$.

Myers N, Mittermeier RA, Mittermeier CG, da Fonseca GAB, Kent J (2000) Biodiversity Hotspots for Conservation Priorities. Nature 403: 853-858 doi: 10.1038/35002501

Rosa Pinto AA (1983) Ornithologia de Angola. Instituto de Investigação Cientifica Tropical, Lisboa, 696 pp.

Ryan PG, Sinclair I, Cohen C, Mills MSL, Spottiswoode CN, Cassidy R (2004) The conservation status and vocalisations of threatened birds from the scarp forests of the Western Angola Endemic Bird Area. Bird Conservation International 14: 247-260. doi: 10.1017/ S0959270904000322

Stattersfield AJ, Crosby MJ, Long AJ, Wege DC (1998) Endemic Bird Areas of the World. BirdLife Conservation Series No. 7. BirdLife International, Cambridge, UK.

Sinclair I, Ryan P (2003) Birds of Africa south of the Sahara, Struik, Cape Town. 


\section{2) References used in developing the database}

Chapman AD, Wieczorek J (Eds) (2006) Guide to Best Practices for Georeferencing. Global Biodiversity Information Facility, Copenhagen, 90 pp.

Gill F, Donsker D (Eds) (2013) IOC World Bird List (v 3.4). http://www.worldbirdnames.org [accessed September 09, 2013]

Specify Software Project (2013) Biodiversity Institute, University of Kansas, 1345 Jayhawk Blvd. Lawrence, KS USA 66045.

Del-Hoyo J, Elliott A, Sargatal J (1992) Handbook of the Birds of the World, Vol. 1. Ostrich to Ducks. Lynx Editions, Barcelona, 696 pp.

Del-Hoyo J, Elliot A, Sargatal J (1994) Handbook of the birds of the world, Vol. 2. New World vultures to Guineafowl. Linx Editions, Barcelona, 638 pp.

Del-Hoyo J, Elliot A, Sargatal J (1996) Handbook of the Birds of the World. Vol. 3. Hoatzin to Auks. Lynx Editions, Barcelona, 821 pp.

Del-Hoyo J, Elliot A, Sargatal J (1997) Handbook of the birds of the World, Vol. 4. Sangrouse to Cuckoos. Lynx Editions, Barcelona, 679 pp.

Del-Hoyo J, Elliot A, Sargatal J (1999) Handbook of the birds of the world, Vol. 5. Barnowls to Hummingbirds. Lynx Editions, Barcelona, 759 pp.

Del-Hoyo J, Elliot A, Sargatal J (2001) Handbook of the birds of the World, Vol. 6. Mousebirds to Hornbills. Lynx Edicions. Barcelona, 589 pp.

Del-Hoyo J, Elliot A, Sargatal J (2002) Handbook of the birds of the World, Vol 7. Jacamars to Woodpeckers. Lynx Editions. Barcelona, 613 pp.

Del-Hoyo J, Elliott A, Christie DA (2003) Handbook of the birds of the world, Vol. 8: Broadbills to Tapaculos. Lynx Editions, Barcelona, $845 \mathrm{pp}$.

Del-Hoyo J, Elliott A, Christie DA (2004) Handbook of the birds of the world, Vol. 9. Cotingas to Pipits and Wagtails. Lynx Editions, Barcelona, 863 pp.

Del-Hoyo J, Elliott A, Christie DA (2005) Handbook of the birds of the world, Vol. 10. Cuckoo-Shrikes to Thrushes. Lynx Editions, Barcelona, 895 pp.

Del-Hoyo J, Elliott A, Christie DA (2006) Handbook of the birds of the world, Vol. 11. Old World Flycatchers to old World Warblers. Lynx Editions, Barcelona, 798 pp.

Del-Hoyo J, Elliott A, Christie DA (2007) Handbook of the birds of the world, Vol. 12. Picathartes to Tits and Chickadees. Lynx Editions, Barcelona, 815 pp.

Del-Hoyo J, Elliott A, Christie DA (2008) Handbook of the birds of the world, Vol. 13. Penduline-Tits to Shrikes. Lynx Editions, Barcelona, 879 pp.

Del-Hoyo J, Elliott A, Christie DA (2009) Handbook of the birds of the world, Vol. 14. BushShrikes to Old World Sparrows. Lynx Editions, Barcelona, 893 pp.

Del-Hoyo J, Elliott A, Christie DA (2010) Handbook of the birds of the world, Vol. 15. Weavers to New World Warblers. Lynx Editions, Barcelona, 879 pp.

Del-Hoyo J, Elliott A, Christie DA (2011) Handbook of the birds of the world, Vol. 16. Tanagers to New World Blackbirds. Lynx Editions, Barcelona, 893 pp. 